\title{
Program Bimbingan Belajar (BIMBEL) Matematika Untuk Siswa SD di Desa Semerap Pada Era Pandemi Covid-19
}

\author{
Decha Veronica $^{1}$, Eline Yanty Putri Nasution ${ }^{2 *}$ \\ ${ }^{1,2}$ Jurusan Tadris Matematika, Institut Agama Islam Negeri (IAIN) Kerinci \\ Email: ${ }^{1}$ veronikadee34@gmail.com, ${ }^{2}$ elineyantyputrinasution@iainkerinci.ac.id
}

\section{INFORMASI ARTIKEL}

\section{Data artikel:}

Naskah masuk, 22 Juli 2021

Direvisi, 28 Agustus 2021

Diiterima, 24 November 2021

\section{Kata Kunci:}

Covid-19 Pandemic

Elementary School

Tutoring Programme

BIMBEL

\begin{abstract}
ABSTRAK
Abstract- The covid-19 pandemic has caused schools to be temporarily closed to avoid crowds and avoid the spread of the coronavirus. That way, school activities continue to run even with online learning, Problems encountered in the community during the current covid-19 pandemic regarding online learning have resulted in a lack of enthusiasm for students to study independently at home without the assistance of a teacher, often the material being taught cannot be understood properly, and there is a decrease in learning achievement. Therefore, this community service activity provides and holds a Tutoring Program (BIMBEL) which aims to help students solve learning difficulties at school. That way, teaching and learning activities will be more efficient so that can be better and more optimal in developing their abilities. The activity was carried out using the face to face teaching method while still adhering to health protocols. The conclusions and results obtained from this program are that there is an increase in students learning enthusiasm and student learning outcomes both cognitively and skillfully.
\end{abstract}

Abstrak- Kegiatan pengabdian kepada masyarakat ini
bertujuan untuk mengatasi permasalahan pembelajaran dari
rumah (Daring) yang ditemui di tengah masyarakat pada masa
pendemi Covid-19. Oleh karena itu diadakan program
Bimbingan Belajar (BIMBEL) sebagai kegiatan Kuliah Kerja
Nyata (KKN) untuk mengatasi penurunan minat, motivasi serta
hasil belajar siswa selama pembelajaran Daring. Sasaran
pengabdian ini adalah 14 orang siswa Sekolah Dasar (SD)
kelas 4 dan kelas 5 di Desa Semerap, Kabupaten Kerinci
Provinsi Jambi. Kegiatan BIMBEL ini dilaksanakan di Posko
KKN-DR IAIN Kerinci 2021 selama dua bulan. Model
pembelajaran yang dilakukan adalah secara langsung (tatap
muka) dengan tetap mematuhi protokol kesehatan. Metode
pembelajaran yang digunakan adalah metode ceramah dan
diskusi. Kegiatan BIMBEL dilaksanakan sebanyak 2 kali
petemuan dalam seminggu selama maksimal 3 jam yang
membahas materi pengayaan yang berkaitan dengan materi
yang sedang diajarkan oleh guru di sekolah. Hasil angket


respon siswa terhadap kegiatan BIMBEL menyimpulkan bahwa $78 \%$ siswa memiliki minat belajar, $86 \%$ siswa memiliki motivasi serta $71 \%$ siswa memiliki hasil belajar yang meningkat setelah mengikuti kegiatan BIMBEL.

\section{Korespondensi:}

\section{Eline Yanty Putri Nasution}

Jurusan Tadris Matematika, Institut Agama Islam Negeri (IAIN) Kerinci

Jalan Kapten Muradi Desa Sumur Jauh Kec. Pesisir Bukit Kota Sungai Penuh Provinsi Jambi

\section{PENDAHULUAN}

Pendidikan di Indonesia saat ini menggunakan Kurikulum 2013 (K13) yang pada dasarnya siswa harus lebih aktif daripada guru (Wanti \& Sari, 2021). Siswa mempresentasiakan apa yang ditangkap dari pembelajaran dan menerapkan ilmu di dalam kehidupan masing-masing (Rijal \& Bachtiar, 2015). Keberhasilan dalam proses pembelajaran selalu dipengaruhi oleh berbagai sebab dan latar belakang, baik dalam lingkungan sekolah, keluarga maupun dari dalam diri siswa itu sendiri.

Aspek pendidikan menjadi salah satu aspek yang banyak mengalami dampak dalam masa pendemi Corona Virus Desease 2019 (Covid-19) di sepanjang tahun 2020. Covid-19 adalah penyakit menular yang disebabkan oleh jenis corona virus yang baru ditemukan. Walaupun virus Covid-19 lebih banyak menyerang manusia lanjut usia (lansia), virus ini sebenarnya bisa juga menyerang siapa saja, mulai dari bayi, anak-anak, hingga orang dewasa. Oleh karena itu, sebagai upaya untuk mencegah penularan virus Covid-19, pemerintah mengeluarkan kebijakan agar sekolah-sekolah meminta siswanya untuk belajar di rumah dengan menerapkan metode pembelajaran siswa secara daring. (KemKes, 2020)

Sejak 1 Juli 2020, pemerintah menerapkan sebuah sistem baru yang diterapkan pasca Pembatasan Sosial Berskala Besar (PSBB), yaitu Adaptasi Kebiasaan Baru. Tatanan kebiasaan baru menjadi upaya menjembatani pembangunan kesehatan dan ekonomi akibat pendemi Covid-19 yang belum jelas kapan selesainya. Adaptasi tatanan kebiasaan baru di tengah pendemi Covid-19 dilakukan oleh berbagai tingkatan pemerintahan dan beberapa pihak secara kolaboratif, tak terkecuali peran perguruan tinggi dalam mewujudkan salah satu Tri Dharma Perguruan Tinggi yaitu Pengabdian Kepada Masyarakat. (Satria et al., 2020)

Terlepas dari diterapkannya kegiatan belajar dari rumah, terdapat kendala nyata pada pelaksanaan kegiatan pendidikan di Desa Semerap Kabupaten Kerinci yaitu kurangnya sarana dan prasarana terkait Teknologi Informasi dan Komunikasi (TIK) khususnya dalam rangka pembelajaran jarak jauh. Hal ini diperoleh berdasarkan hasil observasi (pengamatan) penulis sebagai salah satu warga pada Desa tersebut. Penulis secara langsung menyaksikan kegiatan pembelajaran melalui Dalam Jaringan (Daring) yang dilakukan oleh beberapa orang guru dan siswa. Kemudian penulis melakukan wawancara tidak terstruktur terkait perasaan saat mengikuti pembelajaran Daring. Kurangnya pengetahuan serta keahlian guru dan siswa dalam pemanfaatan media online menjadi faktor internal terjadinya hambatan pembelajaran Daring. Kurangnya fasilitas media elektronik serta tidak terpenuhinya kuota jaringan internet merupakan hal mendasar yang menyebabkan terhambatnya proses pembelajaran Daring. Hal ini selaras dengan pernyataan Kemdikbud RI (2020) yaitu tidak semua peserta didik memiliki fasilitas untuk menunjang pembelajaran daring.

Salah satu kegiatan yang membantu peserta didik untuk mengembangkan diri dalam meningkatkan keberhasilan ptoses 
pembelajaran ialah adanya kegiatan Bimbingan Belajar (BIMBEL).

Bimbingan Belajar memiliki peran penting untuk mendukung keberhasilan pembelajaran. Meskipun bimbingan belajar memberikan pengaruh pada kejenuhan belajar siswa (Nihayah, 2018), namun bimbingan belajar dapat meningkatkan motivasi belajar siswa (Huda, n.d.) dan juga akan diikuti dengan peningkatan nilai akademik (Armiatin et al., 2014); (Fayakunikmah, 2019); (Nurhayati, 2014). Yusuf \& Nurihsan (dalam Zuhron, 2016) menyatakan bahwa bimbingan belajar merupakan suatu bantuan yang diberikan kepada seseorang untuk memecahkan masalah akademis. Abin Syamsudin Makmun (dalam Zuhron, 2016) juga menyatakan bahwa bimbingan belajar adalah suatu bantuan yang diberikan sehingga nantinya individu tersebut dapat memecahkan masalah yang dihadapi dengan kemampuan sendiri. Dengan melakukan program Bimbingan Belajar, diharapkan siswa yang bersangkutan dapat mencapai perkembangan yang maksimal.

Bimbingan belajar adalah bimbingan dalam hal menemukan cara belajar yang tepat, dalam memilih program studi yang sesuai, dan dalam mengatasi kesukaran-kesukaran yang timbul berkaitan dengan tuntunan-tuntunan belajar disuatu institusi pendidikan (El Fiah \& Purbaya, 2016). Bimbingan belajar ini ditandai dengan disediakannya jam pelajaran khusus untuk bimbingan secara kelompok, dan pembimbing berdiri didepan untuk membahas hal-hal yang dirasa perlu untuk menunjang kelancaran dan kesuksesan belajar siswa. hal ini sesuai dengan pendapat (Sujiwo, 2017) menjelaskan bahwa bimbingan belajar dirasakan perlu atau dibutuhkan dalam keseluruhan proses pendidikan karena kegiatan belajar merupakan kegiatan inti dalam keseluruhan proses pendidikan. Karena suatu bimbingan bertujuan untuk mengarahkan individu yang sesuai dengan potensinya secara optimal. Berdasarkan uraian diatas bimbingan belajar diterapkan sebagai sarana untuk membantu siswa dalam mata pelajaran yang belum dimengerti dan dipahaminya.

Pelaksanaan program bimbingan belajar ini menggunakan metode face to face atau pengajaran tatap muka dengan tetap mematuhi protokol kesehatan melalui kegiatan Kuliah Kerja Nyata (KKN). Kuliah Kerja Nyata (KKN) adalah suatu bentuk pendidikan dengan cara memberikan pengalaman belajar kepada mahasiswa untuk hidup di tengah masyarakat di luar lingkungan perguruan tinggi dengan melakukan identifikasi kemudian melakukan penanganan terhadap permasalahan yang sedang dihadapi oleh masyarakat. Menurut Syardiansah, (2019), kegiatan KKN adalah kegiatan intrakurikuler yang memadukan pelaksanaan Tri Dharma Perguruan Tinggi dengan metode pemberian pengalaman belajar dan bekerja kepada mahasiswa dalam kegiatan pemberdayaan masyarakat. Hal tersebut selaras dengan Undang-Undang Republik Indonesia Nomor 20 Tahun 2003 tentang sistem Pendidikan Nasional pada pasal 20 ayat 1 dan pasal 24 ayat 2 yang menyatakan bahwa setiap perguruan tinggi wajib melaksanakan pendidikan, penelitian, dan pengabdian masyarakat.

Kegiatan KKN dilaksanakan di luar lingkungan kampus dengan maksud meningkatkan relevansi pendidikan tinggi dengan perkembangan dan kebutuhan masyarakat akan ilmu pengetahuan, teknologi dan seni untuk melaksanakan pembangunan yang semakin meningkat serta meningkatkan persepsi mahasiswa tentang relevansi antara kurikulum yang dipelajari dikampus dengan realita pembangunan masyarakat. Sebagai mahasiswa, kegiatan KKN sudah seharusnya dilaksanakan sebagai pemahaman belajar yang baru dan tidak pernah diperoleh di dalam kampus.

Dengan adanya pengadaan kegiatan Bimbingan Belajar dalam suatu program kerja Kuliah Kerja Nyata Dari Rumah Berbasis Pemberdayaan Masyarakat (KKN DR-BPM), kiranya bisa mengatasi kesulitan para siswa dalam pembelajaran Daring serta dapat 
membantu para guru dalam perannya sebagai pengajar dalam pembelajaran Daring.

\section{METODE PELAKSANAAN}

Pelaksanaan program KKN DR pada Program Kerja (Proker) Bimbingan Belajar dilakukan untuk jenjang pendidikan SD di Desa Semerap Kecamatan Danau Kerinci Barat di Kabupaten Kerinci Provinsi Jambi. Sasaran pengabdian ini difokuskan kepada siswa kelas 4 dan kelas 5, Program bimbingan belajar diikuti oleh 14 orang siswa SD.

Bimbingan belajar dilaksanakan di Posko KKN-DR IAIN Kerinci 2021 di Desa Semerap. Kegiatan BIMBEL dilaksanakan selama masa KKN-DR mulai dari tanggal 19 Mei sampai dengan 4 Juli 2021. Model pembelajaran yang dilakukan adalah secara langsung (tatap muka) dengan tetap mematuhi protokol kesehatan. Metode pembelajaran yang digunakan adalah metode ceramah dan diskusi. Kegiatan BIMBEL dilaksanakan sebanyak 2 kali petemuan dalam satu minggu setiap hari Selasa dan Kamis pukul 15.00 WIB sampai
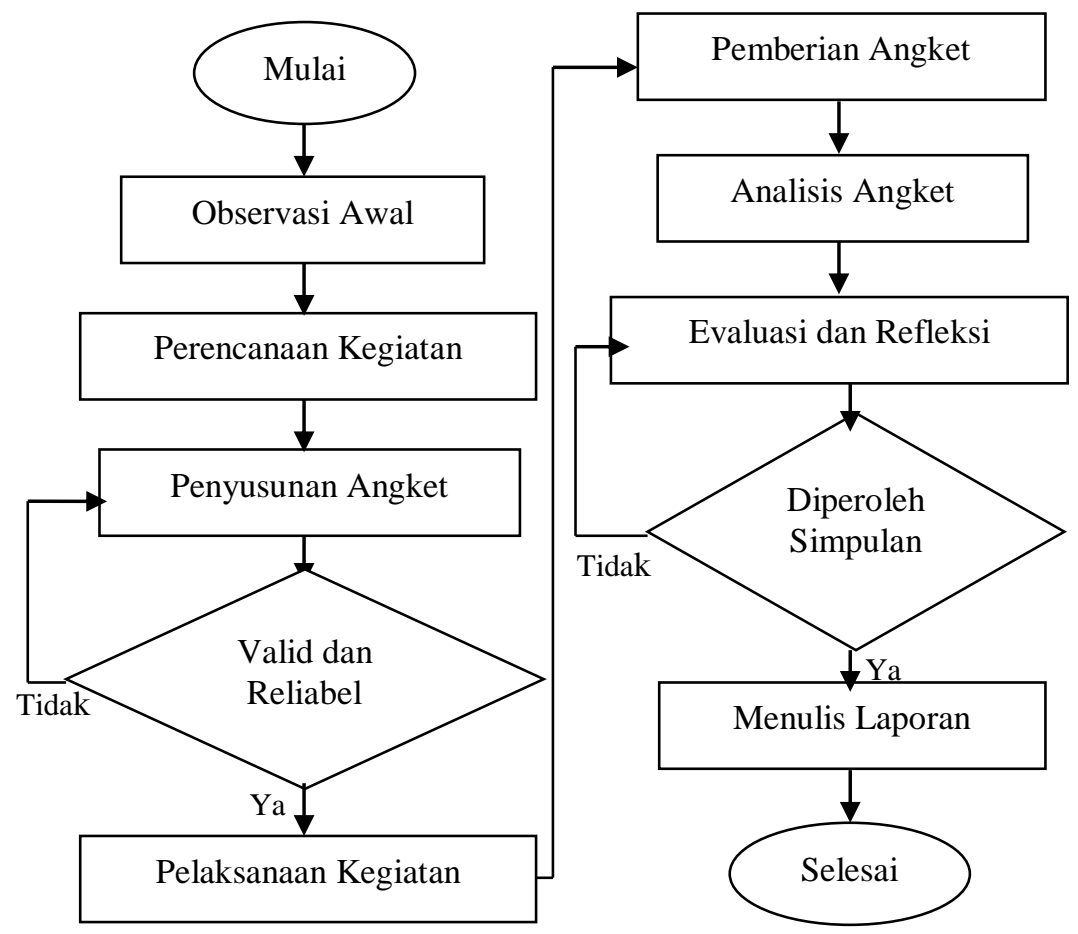

Gambar 1. Tahapan Kegiatan

Kegiatan KKN ini diakhiri dengan pemberian angket untuk mengetahui dengan selesai. Kegiatan atau program pembelajaran adalah berupa pembahasan materi pengayaan yang berkaitan dengan materi yang sedang diajarkan oleh guru di sekolah.

Kegiatan BIMBEL ini menggunakan berbagai sumber belajar untuk siswa SD yang bersesuaian dengan Buku Matematika Guru dan Siswa berdasarkan Kurikulum 2013 Edisi Revisi Tahun 2017. Strategi kegiatan yang digunakan yaitu: (1) melakukan pendekatan emosional dengan siswa; (2) menjalin kerja sama dengan orangtua siswa; (3) menjaga hubungan baik dengan masyarakat setempat; dan (4) mentaati protokol kesehatan selama melaksanakan KKN.

Adapun diagram alir (flowchart) tahapan kegiatan Pengabdian Kepada Masyarakat (PKM) ini dalam rangka kegiatan KKN dipaparkan melalui Gambar 1 berikut: 
berisi 27 item pernyataan yang terlebih dahulu telah diuji validitas dan reliabilitasnya dengan bantuan SPSS sedemikian sehingga layak untuk diberikan kepada siswa. Adapun Angket Respon Siswa selama kegiatan BIMBEL disajikan pada Tabel 1 berikut:

Tabel 1. Angket Respon Siswa

\begin{tabular}{|c|c|}
\hline No & Pernyataan \\
\hline 1. & Saya selalu hadir BIMBEL \\
\hline 2. & $\begin{array}{l}\text { Menurut saya, lebih baik bermain } \\
\text { daripada ikut BIMBEL }\end{array}$ \\
\hline 3. & Saya merasa senang saat BIMBEL \\
\hline 4. & Saya serius belajar saat BIMBEL \\
\hline 5. & $\begin{array}{l}\text { Saya selalu ingin agar kegiatan BIMBEL } \\
\text { cepat selesai }\end{array}$ \\
\hline 6. & $\begin{array}{l}\text { Saya bertanya kepada tutor tentang hal } \\
\text { yang tidak mengerti saat BIMBEL }\end{array}$ \\
\hline 7. & Menurut saya, BIMBEL tidak perlu \\
\hline 8. & Saya malas ikut BIMBEL \\
\hline 9. & $\begin{array}{l}\text { Saya ajak teman untuk bersama-sama } \\
\text { mengikuti BIMBEL }\end{array}$ \\
\hline 10. & Saya ingin jadwal BIMBEL setiap hari \\
\hline 11. & Saya tidak suka BIMBEL \\
\hline 12. & Saya selalu semangat saat BIMBEL \\
\hline 13. & BIMBEL sangat membosankan \\
\hline 14. & Saya menjadi suka matematika \\
\hline 15. & Menurut saya BIMBEL tidak berguna \\
\hline 16. & BIMBEL hanya membuang waktu saja \\
\hline 17. & Saya hanya diam saja saat BIMBEL \\
\hline 18. & Saya selalu menantikan BIMBEL \\
\hline 19. & Nilai saya menurun sejak ikut BIMBEL \\
\hline 20. & $\begin{array}{l}\text { Saya lebih mudah mengerjakan soal } \\
\text { matematika sejak ikut BIMBEL }\end{array}$ \\
\hline 21. & $\begin{array}{l}\text { Saya lebih mudah memahami materi } \\
\text { pelajaran sejak ikut BIMBEL }\end{array}$ \\
\hline 22. & $\begin{array}{l}\text { BIMBEL membuat saya tertantang } \\
\text { menyelesaikan soal matematika }\end{array}$ \\
\hline 23. & $\begin{array}{l}\text { Saya selalu gagal dalam menyelesaikan } \\
\text { persoalan matematika }\end{array}$ \\
\hline 24. & $\begin{array}{l}\text { Saya tidak pernah remedial matematika } \\
\text { karena ikut BIMBEL }\end{array}$ \\
\hline 25. & $\begin{array}{l}\text { Saya selalu memperoleh nilai } \\
\text { matematika yang rendah meskipun telah } \\
\text { ikut BIMBEL }\end{array}$ \\
\hline 26. & $\begin{array}{l}\text { Kemampuan matematika saya berada di } \\
\text { bawah rata-rata kelas }\end{array}$ \\
\hline & $\begin{array}{l}\text { Nilai matematika saya selalu di bawah } \\
\text { KKM }\end{array}$ \\
\hline
\end{tabular}

Angket menggunakan skala likert dengan lima pilihan respon yaitu Sangat Setuju, Setuju, Netral, Tidak Setuju, dan Sangat Tidak Setuju. Angket disusun berdasarkan indikator Minat, Motivasi dan Hasil Belajar Siswa masing-masing berjumlah sembilan item pernyataan yang terdiri dari pernyataan positif dan negatif yang disusun secara secara acak. Angket diberikan kepada seluruh siswa setelah kegiatan BIMBEL selesai. Setelah seluruh siswa selesai mengisi angket maka dilakukan analisis data angket untuk memperoleh kesimpulan terkait minat, motivasi dan hasil belajar matematika siswa setelah mengikuti kegiatan BIMBEL.

\section{HASIL DAN PEMBAHASAN}

Menurut Purwanto dkk. (2020), dampak pandemi Covid-19 terhadap proses pembelajaran online di tingkat Sekolah Dasar berdampak terhadap siswa. Beberapa dampak yang dirasakan oleh siswa yaitu siswa belum ada budaya belajar jarak jauh karena selama ini sistem belajar yang dilaksanakan adalah secara tatap muka.

Siswa terbiasa berada di sekolah untuk berinteraksi dengan teman-temannya serta bertatap muka dengan guru, dengan adanya metode pembelajaran jarak jauh membuat siswa perlu waktu untuk beradaptasi dan menghadapi perubahan baru yang secara tidak langsung akan memengaruhi daya serap belajar siswa.

Hasil dari kegiatan Bimbingan Belajar (BIMBEL) yang telah dilakukan yaitu dapat membuat siswa mempunyai semangat untuk mengikuti pembelajaran secara Daring yang dilakukan oleh sekolah, siswa mempunyai sarana atau wadah untuk bertanya dan belajar, dan siswa merasa terbantu dalam menyelesaikan tugas yang diberikan oleh guru di sekolah. Respon dari siswa peserta BIMBEL adalah sangat baik dimana siswa sangat antusias untuk mengikuti kegiatan Bimbingan Belajar (BIMBEL) dari awal pelaksanaan sampai dengan akhir pelaksanaan 


\section{kegiatan Bimbingan Belajar (BIMBEL)} selama periode KKN-DR IAIN Kerinci 2021.

Berdasarkan hasil angket respon siswa, sebanyak $78 \%$ siswa menyatakan senang terhadap pelaksanaan BIMBEL. Adapun 22\% siswa lainya menyatakan kurang berminat dalam mengikuti BIMBEL. Selanjutnya, $86 \%$ siswa menunjukkan motivasi belajar pada saat BIMBEL. Motivasi dan Minat siswa ini juga berbanding lurus dengan Hasil Belajar Siswa, yaitu sebanyak $71 \%$ siswa menyatakan mengalami peningkatan hasil belajar. Adapun hasil angket respon siswa dipaparkan pada Tabel 2 berikut:

Tabel 2. Hasil Angket Respon Siswa

\begin{tabular}{|c|c|c|c|c|c|}
\hline \multirow{3}{*}{ No. } & \multirow{3}{*}{ Indikator } & \multicolumn{4}{|c|}{ Respon Siswa } \\
\hline & & \multicolumn{2}{|c|}{ Positif } & \multicolumn{2}{|c|}{ Negatif } \\
\hline & & Jlh & $\%$ & Jlh & $\%$ \\
\hline 1. & Minat & 11 & 78 & 3 & 22 \\
\hline 2. & Motivasi & 12 & 86 & 2 & 14 \\
\hline 3. & Hasil Belajar & 10 & 71 & 4 & 29 \\
\hline & Rata-Rata & 11 & 78 & 3 & 22 \\
\hline
\end{tabular}

Dari data pada Tabel 2 di atas tampak bahwa rata-rata $78 \%$ siswa memberikan respon positif terhadap pelaksanaan kegiatan BIMBEL. Sementara itu, hanya 3 orang (22\%) siswa peserta BIMBEL yang memberikan respon negatif terhadap pelaksanaan kegiatan BIMBEL

Adapun hasil angket respon siswa dipaparkan pada gambar 2 berikut:

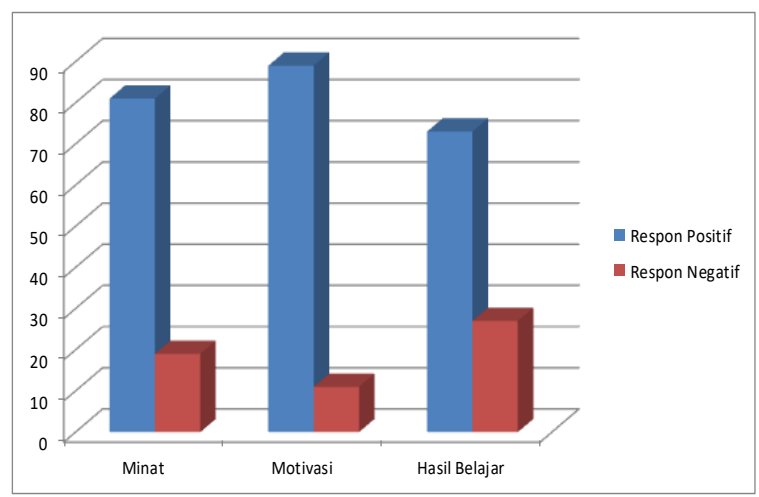

Dari gambar 2 di atas dapat disimpulkan bahwa kegiatan BIMBEL mampu mengatasi permasalahan minat, motivasi dan hasil belajar siswa pada pembelajaran Matematika yang belajar secara Daring selama pandemi Covid-
19. Dengan adanya kegiatan mahasiswa yang sedang mengikuti Kuliah Kerja Nyata (KKN), ternyata dapat berperan dalam menyelesaikan permasalahan yang sedang dihadapi masyarakat yang juga selaras dengan Program Kerja (Proker) yang telah direncanakan oleh Pemerintah Desa. Kegiatan KKN ini juga menjadikan Pemerintah Desa dapat menjalin hubungan silaturahim dengan perguruan tinggi sebagai mitra kerja.

Dokumentasi kegiatan pengabdian kepada masyarakat yang telah dilaksanakan ditunjukkan pada gambar 3 sampai gambar 8 dibawah ini.

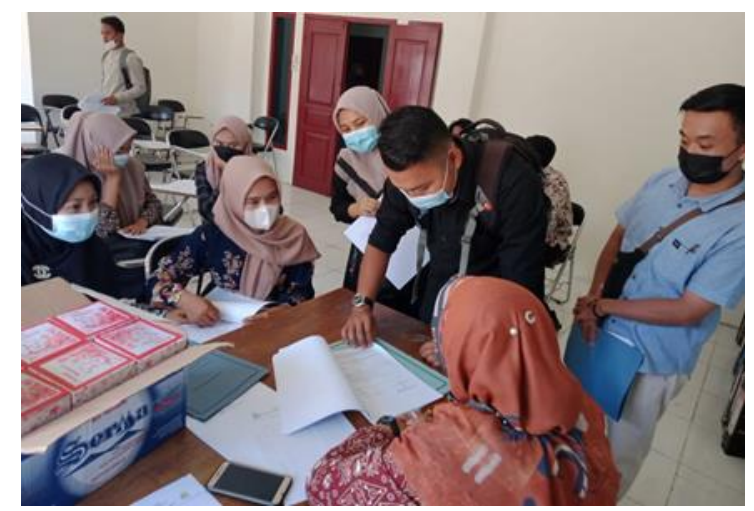

Gambar 3. Bimbingan dengan Dosen Pembimbing Lapangan KKN

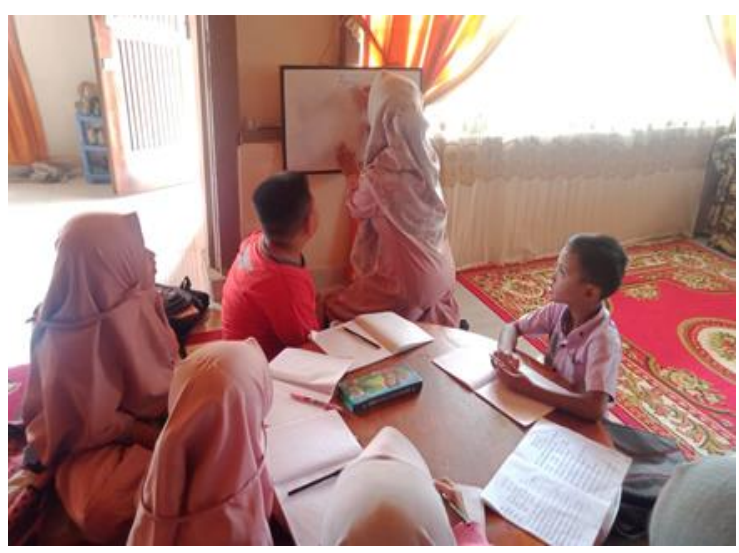

Gambar 4. Kegiatan BIMBEL 


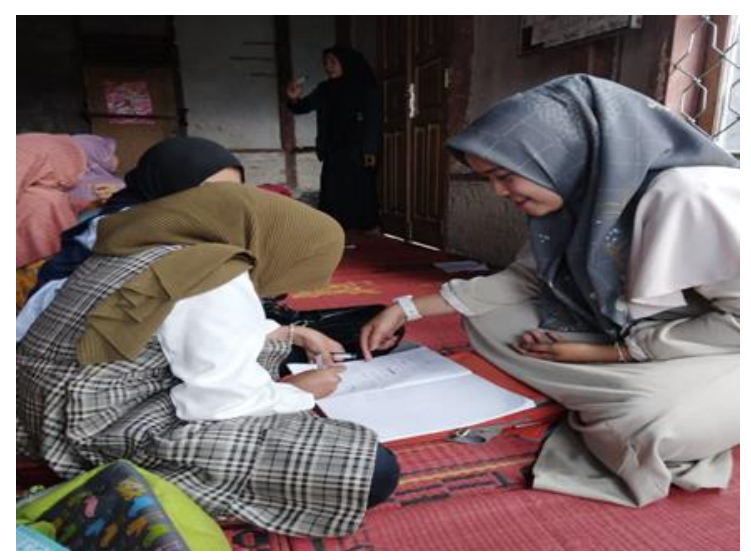

Gambar 5. Kegiatan Bimbingan Siswa

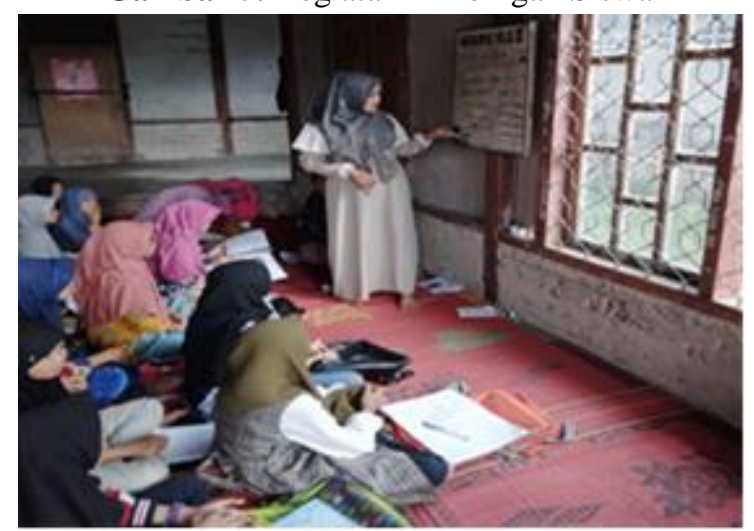

Gambar 6. Proses Belajar Mengajar

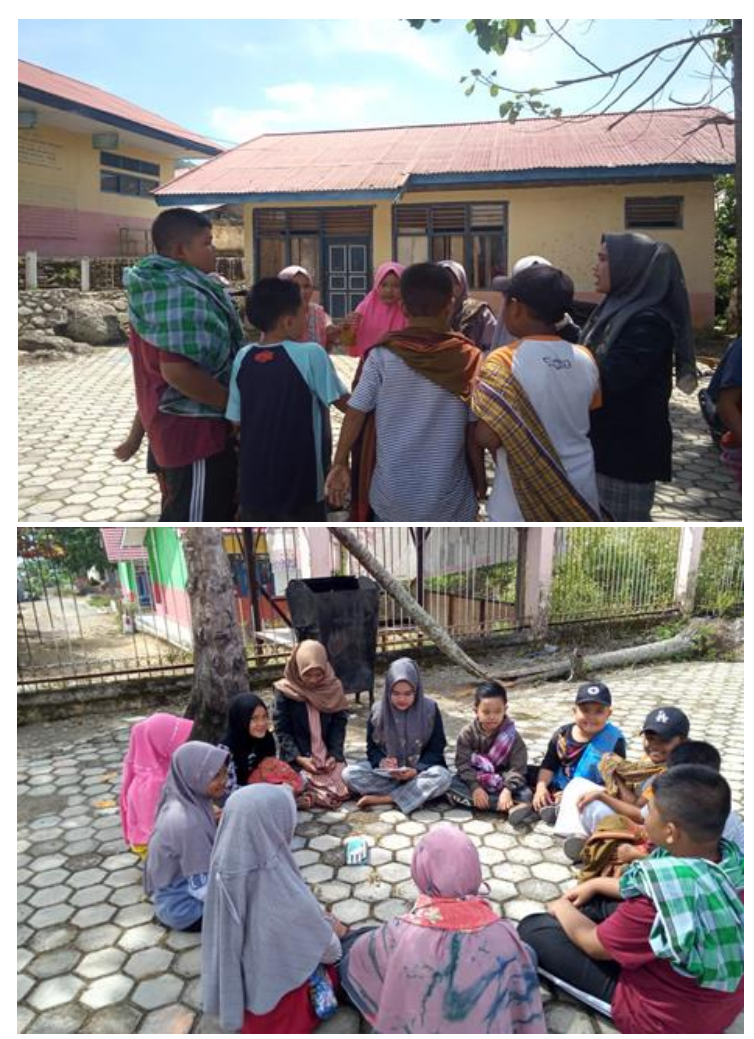

Gambar 7. Kegiatan Outbond

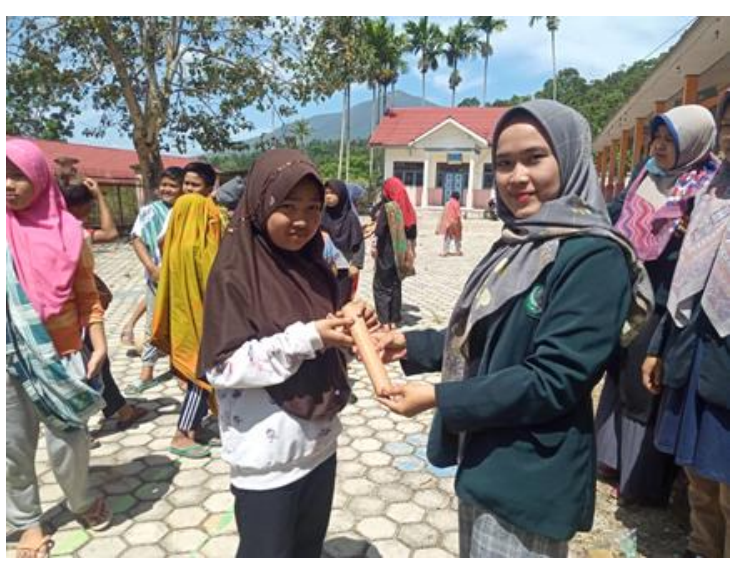

Gambar 8. Pemberian Doorprize Kepada Peserta Berprestasi pada Program BIMBEL

\section{KESIMPULAN}

Kesimpulan dalam pengabdian masyarakat mengenai bimbingan belajar di masa pandemi ini berajalan dengan lancar sesuai dengan rancangan pelaksanaan bimbingan belajar pada program kerja KKNDR IAIN Kerinci. yang kemudian Hasil dari bimbingan belajar yaitu dapat membuat siswa mempunyai semangat untuk mengikuti pembelajaran secara daring yang dilakukan oleh sekolah, siswa mempunyai sarana atau wadah untuk bertanya dan belajar, dan siswa merasa terbantu dalam menyelesaikan tugas yang diberikan oleh guru di sekolah. Respon dari siswa sangat baik dan antusias untuk mengikuti bimbingan belajar dari awal sampai akhir pelaksanaan bimbingan belajar selama periode KKN-DR IAIN Kerinci 2021.

Berdasarkan hasil angket respon siswa diperoleh bahwa mayoritas siswa peserta BIMBEL menunjukkan respon yang positif terhadap pelaksanaan kegiatan BIMBEL, yaitu $78 \%$ siswa memiliki minat belajar, $86 \%$ siswa memiliki motivasi serta $71 \%$ siswa memiliki hasil belajar yang meningkat setelah pelaksanaan BIMBEL. Untuk itu, kegiatan ini sangat dianjurkan untuk dilaksanakan secara berkelanjutan guna antisipasi adanya pembelajaran daring di sekolah selama pandemi Covid-19.

\section{DAFTAR PUSTAKA}

Armiatin, Septiwihartini, D., \& Mahasiswa, Y. 
G. (2014). Meningkatkan Hasil Belajar Siswa Pada Mata Pelajaran PKn Di Kelas V SdN No. 4 Pangalasiang Melalui Bimbingan Kerja Kelompok. Jurnal Kreatif Online, 3(4), 200-214.

El Fiah, R., \& Purbaya, A. P. (2016). Penerapan Bimbingan Belajar dalam Meningkatkan Hasil Belajar Peserta Didik di SMP Negeri 12 Kota Bandar Lampung Tahun Pelajaran 2015/2016. KONSELI: Jurnal Bimbingan Dan Konseling (E-Journal), 3(2), 161-174.

Fayakunikmah, G. M. (2019). Kontribusi Keikutsertaan Bimbingan Belajar Dan Motivasi Belajar Terhadap Nilai Akademik Siswa Kelas Xii Jurusan Pemasaran Di Lbb Epsilon Gresik Gressynta Meidyna Fayakunikmah. 07(03).

Huda, J. (n.d.). Meningkatkan Motivasi Belajar Siswa Melalui Optimalisasi Layanan Bimbingan Belajar Secara Kelompok Dan Individu. 35-45.

Kemdikbud RI. (2020). Panduan Pembelajaran Jarak Jauh. Kementrian Pendidikan Dan Kebudayaan, 021, 28.

KemKes. (2020). Pedoman Kesiapan Menghadapi Coronavirus Disease (COVID-19). Direktoral Jenderal Pencegahan Dan Pengendalian Penyakit.

Nihayah, N. (2018). Pengaruh Bimbingan Belajar terhadap Kejenuhan dalam Belajar pada Siswa Kelas XI di SMAN I Gerung Kabupaten Lombok Barat. ELHIKMAH: Jurnal Kajian Dan Penelitian Pendidikan Islam, 12(1), 53-64. https://doi.org/10.20414/elhikmah.v12i1. 241

Nurhayati. (2014). Meningkatkan Hasil Belajar Siswa Dengan Menggunakan Metode Bimbingan Mata Pelajaran IPA di Kelas III SD Inpres 1 Bainaa. Jurnal Kreatif Tadulako Online, 4(10), 1-11.

Purwanto, A., Pramono, R., Asbari, M., Santoso, P. B., Wijayanti, L. M., Hyun, C. C., \& Putri, R. S. (2020). Studi Eksploratif Dampak Pandemi COVID-19
Terhadap Proses Pembelajaran Online di Sekolah Dasar. 2, 1-12.

Rijal, S., \& Bachtiar, S. (2015). Hubungan antara Sikap , Kemandirian Belajar, dan Gaya Belajar dengan Hasil Belajar Kognitif Siswa. 3(2), 15-20.

Satria, B. A., Hasanah, N. H., \& Rudiansyah, R. (2020). Penyuluhan Adaptasi Tatanan Kebiasaan Baru Desa Tangguh Covid-19. Anoa: Jurnal Pengabdian Masyarakat Sosial, Politik, Budaya, Hukum. Ekonomi, $1(3), \quad 107$. https://doi.org/10.52423/anoa.v1i3.13242

SUJIWO, D. A. C. (2017). Bimbingan Belajar Matematika Pada Siswa Sd Desa Kalidilem Lumajang. Jurnal Terapan Abdimas, $2, \quad 41$. https://doi.org/10.25273/jta.v2i0.975

Syardiansah. (2019). Peranan Kuliah Kerja Nyata Sebagai Bagian Dari Pengembangan Kompetensi Mahasiswa. 57-68.

Wanti, L. P., \& Sari, L. (2021). Pada Pengembangan Pembelajaran Matematika Berbasis Multimedia. 12(01), 9-15. https://doi.org/10.35970/infotekmesin.v1 $2 \mathrm{i} 1.279$ 